https://doi.org/10.52058/2695-1592-2021-7(7)-235-252

\title{
Поліна Якименко
}

кандидат педагогічних наук, дочент

кафедри психології та педагогічної освіти,

Міжнародний класичний університет ім. Пилипа Орлика

Миколаїв, Україна, е-таil: serdolik1 @hotmail.com

https://orcid.org/0000-0003-4230-9586

\section{СПЕЦИФІКА ПІДГОТОВКИ МАЙБУТНІХ УЧИТЕЛІВ АНГЛІЙСЬКОЇ МОВИ ДО ПРОФІЛЬНОГО НАВЧАННЯ СТАРШОКЛАСНИКІВ}

Анотація. Система освіти повинна реагувати на зміни в суспільстві, тому місією сучасних педагогічних закладів вищої освіти є підготовка педагога готового та здатного приймати сучасні виклики та відповідати запитам суспільства.

У статті розглядається проблема професійної підготовки майбутніх учителів англійської мови до профільного навчання старшокласників. Уточнено поняття «професійна підготовка майбутніх учителів англійської мови». Здійснено аналіз становлення процесу професійної підготовки майбутніх фахівців до профільного навчання старшокласників. Окреслено основні тенденції у галузі вищої педагогічної іншомовної освіти та вимоги до рівня професійної підготовки сучасного вчителя англійської мови. Обгрунтовано специфіку фахової підготовки майбутніх педагогів 3 урахуванням традицій та позитивного досвіду організації навчальновиховного процесу у вищому навчальному закладі.

Ключові слова: професійна підготовка, компетентнісний підхід, майбутній учитель англійської мови, профільне навчання, старшокласники, профілізація.

\section{Polina Yakymenko}

Candidate of Pedagogical Sciences, Associate Professor

Department of Psychology and Pedagogical Education

International Classical University. Philip Orlik

Mykolaiv, Ukraine, e-mail: serdolik1@hotmail.com https://orcid.org/0000-0003-4230-9586

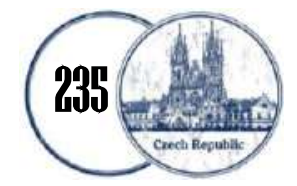




\section{SPECIFIC TRAINING OF FUTURE ENGLISH TEACHERS FOR THE SPECIALIZED TRAINING OF SENIOR PUPILS}

Abstract. The education system must respond to changes in society, therefore, the mission of modern pedagogical institutions of higher education is to prepare a teacher who is ready and able to accept modern challenges and meet the needs of society.

The article deals with the problem of professional training of future English teachers for specialized training of senior pupils. The concept of "professional training of future English teachers" has been clarified. The analysis of the formation of the process of professional training of future specialists for specialized training of senior pupils is carried out. The main trends in the field of higher pedagogical foreign language education and the requirements for the level of professional training of modern English teacher are outlined. The specificity of the professional training of future teachers has been substantiated, taking into account the traditions and positive experience of organizing the educational process in a higher educational institution.

Keywords: professional training, competence approach, future English teacher, specialized training, senior students, profiling.

Постановка проблеми. Сучасні тенденції європеїзації іншомовної освіти в Україні спрямовані на оновлення цілей і змісту навчання та вивчення іноземних мов у закладах середньої та вищої освіти, що висуває високі вимоги до підготовки учителів іноземних мов нової генерації, професійно готових здійснювати освітній процес в умовах плюрилінгвізму і полілогу культур.

Одним із пріоритетних напрямів сучасної освіти в Україні $є$ профілізація iii змісту в старшій школі. Профільне навчання має найбільшою мірою враховувати інтереси, нахили і здібності, можливості кожного школяра, у тому числі 3 особливими освітніми потребами, у контексті соціального та професійного самовизначення і відповідності вимогам сучасного ринку праці. Такий підхід до організації освіти старшокласників не лише найповніше реалізує принцип особистісно орієнтованого навчання, а й дає змогу створити найоптимальніші умови для їхнього професійного самовизначення та подальшої самореалізації [7].

Аналіз останніх досліджень $\mathbf{i}$ публікацій. На сьогодні в теорії та практиці педагогічної освіти накопичені значні наукові напрацювання, що розкривають зміст підготовки майбутнього вчителя іноземних мов. Вагомий внесок у вивчення цього питання здійснили у своїх працях такі науковці: О. Абдуліна, І. Адольф, Т. Бочарнікова, В. Горова Демченко, Н. Кузьміна, В. Сластьоніна, А. Спіріна, В. Степанова, І. Пасов, В. Шаповалов та ін. 
Мета статті. - розкрити особливості практичної підготовки майбутніх учителів англійської мови до профільного навчання старшокласників.

Виклад основного матеріалу. Теоретичною базою впровадження профільного навчання є Закони України «Про освіту», «Про загальну середню освіту», Концепції профільного навчання у старшій школі, Державному стандарті базової і повної загальної середньої освіти та інших нормативноправових документах. Основні теоретичні напрацювання вітчизняних i зарубіжних учених з урахуванням практичного досвіду в організації навчання старшокласників утілено в Концепції профільного навчання у старшій школі. Цей документ визначає базові поняття й основні підходи до вирішення проблеми профільності старшої школи: окреслює сутність, мету і принципи організації профільного навчання, його структуру i форми організації, розкриває призначення допрофільної підготовки як невід’ємного компонента профільного навчання.

У Концепції профільного навчання у старшій школі одним із пріоритетних напрямів освітньої політики визначено створення системи профільного навчання у 10-11-х класах загальноосвітніх навчальних закладів (ЗНЗ).

Основними цілями запровадження профільного навчання є:

- забезпечення профільного (розширеного) вивчення окремих навчальних предметів згідно з програмами загальної середньої освіти;

- створення умов для істотної диференціації змісту навчання старшокласників із широкими і гнучкими можливостями побудови ними індивідуальних освітніх програм;

- сприяння встановленню рівного доступу до повноцінної освіти різним категоріям учнів відповідно до їхніх здібностей, індивідуальних нахилів і потреб;

- розширення можливостей соціалізації школярів, забезпечення наступності між загальною і професійною освітою, у тому числі ефективнішої підготовки випускників школи до засвоєння програм вищої професійної освіти;

- виховання особистості, здатної до самореалізації, професійного зростання та мобільності в умовах реформування сучасного суспільства. Профільне навчання IM є цілеспрямованою підготовкою учнів до подальшої навчальної i/або професійної діяльності, пов'язаної з використанням IM як об’єкта майбутньої спеціальності або як засобу професійної комунікації [7].

Науково-теоретичний аналіз підготовки майбутніх учителів англійської мови до профільного навчання неможливий без глибокого системного вивчення детермінант, відсутність орієнтації в яких негативним чином позначається на готовності студентів до викладання у старшій школі. Тому логічним напрямком підготовки майбутніх учителів до профільного навчання $€$ для нас аналіз профілізації старшої школи як цілісної педагогічної системи. 
Усі сучасні інноваційні перетворення в українській педагогічній думці 3 модернізації змісту освіти характеризуються підвищенням iї якості, гуманізацією, формуванням єдиного освітнього простору з країнами Європи, що вимагає формування нової генерації майбутніх учителів.

Професійна підготовка вчителя англійської мови в умовах впровадження ідей нової української школи, що полягають у переході від трансляційної педагогіки до смислової, від авторитаризму до педагогічної кооперації, концептуально переосмислюється, що пов'язано зі зміною методологічних основ освіти в цілому.

Модернізація національної шкільної освіти пов'язана також із запровадженням профільного навчання, що вимагає якісних змін у професійній підготовці вчителя англійської мови. Нинішня школа, як ніколи, потребує ініціативних, творчих, креативних, мобільних педагогів, готових до постійної самоосвіти і саморозвитку, пошуку ефективних форм навчання, орієнтованих на інноваційні педагогічні технології.

Дотримання Болонських принципів, зокрема впровадження двоциклового навчання та освітніх і кваліфікаційних ступенів (бакалавра i магістра) $\epsilon$ гарантією підготовки саме таких учителів. У Галузевому стандарті вищої освіти, освітньо-кваліфікаційної характеристики бакалавра за кваліфікацією вчителя німецької, англійської мов і зарубіжної літератури відображено вимоги до компетентності та соціально важливих якостей сучасного вчителя іноземних мов, ключовими серед яких $\epsilon$ оволодіння системою сучасних лінгвокультурологічних знань, специфікою мовних картин світу, вміння використовувати іноземну мову для розвитку інтелекту та впливу на емоційну й пізнавальну сфери особистості учня, окреслення шляхів формування інтелектуальної та емоційної сфер особистості учня, вміння аналізувати досвід роботи, здійснювати самоконтроль, самооцінку, саморегуляцію, виділяти та переборювати недоліки у професійній діяльності [8].

Як зазначає Г. Бойко, формування у студентів готовності до професійної діяльності вчителя іноземної мови передбачає виконання комплексу навчальних заходів, які мають забезпечити майбутнім учителям достатній рівень майстерності на основі засвоєння професійних знань:

- $\quad$ основних положень загальнодержавної політики в галузі шкільної освіти, у тому числі з навчання іноземних мов;

- системи мови та основних лінгвістичних і лінгводидактичних категорій, механізм мовлення, а також історії, культури, сучасних проблем країни, мова якої вивчається, - усім тим, що охоплює поняття комунікативної компетенції, основними компонентами якої є мовна (лінгвістична), мовленнєва та соціокультурна компетенції;

- основних закономірностей процесу навчання іноземної мови, а також змісту і особливостей усіх компонентів цього процесу: цілей, 
методів, засобів тощо;

- психологічних особливостей учня, сфер його інтересів i схильностей, закономірностей оволодіння іноземною мовою в умовах школи, у тому числі різноманітних умов, які існують на сьогодні;

- $\quad$ змісту програми 3 навчання іноземних мов та інших директивних документів;

- основних положень дидактико-методичної концепції, на якій побудований зміст підручника, що він використовує у практиці власної педагогічної діяльності;

- $\quad$ основних вимог, які визначає суспільство до особистості сучасного вчителя, у тому числі рівня його професійної майстерності [6].

Парадигмальні перетворення у шкільній освіті об'єктивно потребують нових підходів до підготовки майбутнього вчителя. У зв'язку 3 цим професійна компетентність як результат ефективної підготовки майбутніх учителів англійської мови розглядається як необхідна умова освітньої діяльності, саморозвитку і самовдосконалення педагога.

Варто зазначити, що організація у закладах вищої освіти професійної підготовки майбутніх учителів англійської мови має певні особливості, які грунтуються на інтегрованому підході до забезпечення змісту навчальновиховного процесу.

При цьому на будь-якому етапі формування можна виділити такі загальні елементи: мотиваційно-цільовий, що вказує на наявність мотиву досягнення мети, інтерес та готовність до роботи; когнітивний як наявність відповідних знань, умінь і здатності використання інформаційної техніки; операційнодіяльнісний, що демонструє ефективність інформаційної діяльності із застосуванням інформаційних технологій; рефлексивний - забезпечує готовність до пошуку вирішення проблем, творчого потенціалу особистості учня [10].

Надзвичайно важливим на сучасному етапі розвитку вищої освіти України $\epsilon$ впровадження у навчальний процес британського досвіду використання інноваційних педагогічних технологій (мовне портфоліо; тьюторство; технології контекстно-мовного навчання - імерсійного навчання, технології мовного занурення і прямої технології навчання; індивідуалізації та персоніфікації навчального процесу - технології навіювання, технології асоціативних символів і технологія асоціацій, побудова інтелектуальних мап; творчо-діалогічних технологій, оскільки профільна освіта старшокласників базується на особистісно орієнтованих підходах, що передбачають упровадження інноваційних педагогічних технологій та інтерактивних методів навчання. Майбутній учитель англійської мови у процесі профільного навчання старшокласників має володіти методикою формування їхньої самоосвітньої компетентності, що базується на спеціально організованій 
педагогом діяльності та включає формування таких якостей, як самостійність, спостережливість, відповідальність, самоорганізація, креативність. Світосприймання та специфіка проявляються в умінні виявляти різні форми активності та володіння інформаційно-технологічною компетентністю. Необхідно враховувати, що ключові компетентності тісно пов'язані з самоосвітніми, як системою здібностей, що забезпечують особистості можливість успішно вирішувати всі життєві завдання, успішно здійснювати життєдіяльність на рівні життєтворчості [10].

Майбутній учитель англійської мови профільного навчання у старшій школі повинен володіти такими практичними навичками:

- структурування навчального матеріалу на основі дидактичних принципів профільного навчання, вибір необхідних для засвоєння одиниць змісту i визначення їх послідовності у рамках навчального курсу, проєктування навчальних засобів і планування їх використання;

- планування педагогічної i навчальної діяльності, що дозволяє визначати конкретні цілі профільного навчання, планувати структуру навчальних профільних ситуацій та діяльності старшокласників у них, визначати способи і форми засвоєння учнями поглибленого змісту англійської мови та їх готовності до зовнішнього незалежного оцінювання, визначати цілі, види і форми проведення діагностики якості навчальних досягнень, вибирати дидактично доцільні методи і прийоми навчання для забезпечення якісного виконання навчальної програми відповідно до вимог Державного стандарту середньої освіти;

- виявлення схильностей і здібностей старшокласників до вивчення англійської мови;

- здійснення максимальної диференціації навчального процесу за предметною спрямованістю інтересів і здібностей учня;

- механізми формування взаємної відповідальності педагога і учнів щодо процесів та результатів навчання через використання різних комунікативних технік і технік організації групової роботи, що дозволяють організовувати учнів на проєктування власної освітньої траєкторії, аналіз іiі результатів через здійснення контролю і корекції навчальної діяльності учнів;

- діяльність, що дозволяє стимулювати пізнавальну активність учнів, встановлювати і підтримувати позитивний психологічний клімат у колективі.

Отже, резюмуючи зазначене вище, нами зроблено висновок, що майбутній учитель англійської мови профільної старшої школи повинен володіти трьома підсистемами впровадження форм і методів профільного навчання: викладення змісту профільного навчального матеріалу, організації комунікації «учитель - учень», забезпечення пізнавальної мотивації учнів до вивчення англійської мови.

Професійна підготовка майбутнього вчителя англійської мови до 
профільного навчання старшокласників на основі діяльнісного підходу передбачає: особистісно-професійне становлення студента, що становить собою цілісну сукупність його освітніх професійних цінностей; спосіб навчальної діяльності; прояв творчості в навчальному процесі; специфічний спосіб самореалізації, самовизначення і соціальної самоактуалізації (тобто, навчання студентів відбувається в умовах індивідуально орієнтованого підходу, у якому студент займає позицію самоуправління своєю навчальнопізнавальною діяльністю із врахуванням власного особистісного досвіду).

При цьому студент сам встановлює індивідуальний освітній «вектор» власного професійного розвитку у контексті підготовки до роботи у старшій профільній школі. Нові, порівняно з традиційною освітою, завдання розвитку особистісно-інтелектуальних ресурсів учнів передбачають співтворчість учня і вчителя у проєктуванні змісту профільної освіти 3 метою забезпечення особистісного ставлення учня до вивчення англійської мови. Така модель освіти, за Н. Гафуровою, характеризується такими принципами [5]:

- визнання людини головною цінністю в освіті, метою якої є створення умов для її особистісного розвитку із врахуванням іiі життєвого досвіду, потреб і здібностей;

- активізація особистісного потенціалу учня та його перехід у позицію суб’єкта освітньої діяльності;

- різноманітність і багатофункціональність освітньої сфери, спрямованої на розвиток мисленнєвої сфери і всебічний розвиток особистості за: освітніми галузями;

- теоретична і практична спрямованість;

- забезпечення реалізації суб'єктної позиції учня через надання йому права проєктування освітньої діяльності на основі вибору змісту освіти варіативної частини і побудови власної освітньої траєкторії;

- стимулювання пізнавальної діяльності старшокласників в умовах процесуальних проблемно-діалогових педагогічних технологій і суб'єктсуб'єктних відносин у спільній діяльності;

- переорієнтація оцінної діяльності педагога 3 традиційної оцінки результатів освітньої діяльності на критерій успішності учня.

Відтак, сучасна профільна школа висуває високі вимоги до професійної компетентності майбутнього вчителя англійської мови: він повинен бути спеціалістом високого рівня, відповідного профілю та спеціалізації, щоб забезпечувати варіативність та особистісну орієнтацію освітнього процесу через послідовне, педагогічно доцільне проєктування індивідуальних освітніх програм розвитку особистості; забезпечувати практичну орієнтацію освітнього процесу засобами впровадження інноваційних інтерактивних технологій, проєктно-дослідницьких методів, партнерської співпраці з учнями. Мета профільного навчання узгоджується 3 головною метою української системи 
освіти, якою $є$ створення умов для розвитку й самореалізації кожної особистості як громадянина України, формування покоління, здатного навчатися упродовж життя (Національна доктрина розвитку освіти).

У зв'язку із визначеною метою система освіти має забезпечити: формування особистості як професіонала, що усвідомлює свою приналежність до сучасної цивілізації; розвиток у підростаючого покоління творчих здібностей, підтримку обдарованих дітей та молоді, формування навичок самоосвіти і самореалізації особистості; підготовку людей високої освіченості й культури, кваліфікованих спеціалістів, здатних до творчої праці, професійного розвитку, мобільності в освоєнні та впровадженні новітніх технологій; різноманітність типів і видів закладів освіти, варіативність навчальних програм, індивідуалізацію навчання й виховання; доступ до якісної освіти в системі загальної середньої освіти; оптимізацію структури освітньої мережі, створення умов для профільного, екстернатного і дистанційного навчання; варіативність здобуття повної загальної середньої освіти відповідно до здібностей та індивідуальних можливостей; неперервність освіти впродовж усього життя; наступність змісту і координацію освітньої діяльності на різних ступенях освіти; формування потреби і здатності до самонавчання відповідно до інтелектуальних можливостей особистості.

При цьому на будь-якому етапі формування можна виділити такі загальні елементи: мотиваційно-цільовий, що вказує на наявність мотиву досягнення мети, інтерес та готовність до роботи; когнітивний як наявність відповідних знань, умінь і здатності використання інформаційної техніки; операційнодіяльнісний, що демонструє ефективність інформаційної діяльності із застосуванням інформаційних технологій; рефлексивний - забезпечує готовність до пошуку вирішення проблем, творчого потенціалу особистості учня [10].

Таким чином, педагогічну підготовку майбутнього вчителя англійської мови, можна реалізувати повніше, якщо ii головна мета буде полягати в орієнтації на професійно-особистісний розвиток, виражений, перш за все, в його здатності до постійного збагачення своєї духовної, фахової, педагогічної та професійної культури в цілому. Даний процес повинен здійснюватися 3 урахуванням основних стадій становлення особистості як суб'єкта діяльності (адаптація студентів до нових соціально-педагогічних умов навчання, становлення активної позиції того, кого навчають, самовизначення), шляхом насичення гуманістичним змістом традиційних курсів психолого-педагогічних дисциплін на факультетах іноземної філології університетів, зокрема педагогічних (Радую, 2014).

Таким чином, викладання дисциплін педагогічного циклу повинно здійснюватись як супровід i забезпечення професійного розвитку i 
саморозвитку майбутнього вчителя англійської мови через організацію різних видів як педагогічної, так і інших видів діяльності. Сучасна концепція педагогічної підготовки майбутнього вчителя іноземних мов передбачає зміни iï пріоритетів:

1.Специффічні ияілі: актуалізація $i$ розвиток особистісних $і$ суб'єктних функиій індивіда.

2. Зміст, в якому освітній стандарт органічно поєднується 3 особистісним досвідом того, кого навчають.

3. Технології, щяо забезпечують затребуваність особистісних функиій $i$ особистісного рівня самореалізачії індивіда.

Центральним положенням особистісного підходу $є$ новий погляд на особистість студента і викладача ЗВО, який включає такі основні позиції: особистість студента є унікальним явищем, тому вона заслуговує на повагу (навіть якщо не є зразковою); особистість як студента, так і викладача, іiі професійний розвиток $\epsilon$ метою педагогічної системи університету; студент $\epsilon$ не об'єктом, а суб'єктом психолого-педагогічної підготовки.

Провідною ідеєю при переосмисленні педагогічної підготовки $є$ ідея активної ролі студента в розвитку його особистісних і професійних здібностей і якостей, тобто примат «суб'єктності», високий рівень розвитку суб'єктивного контролю. Педагогічна підготовка повинна бути в більшій мірі розвиваючою, саморозвиваючою і персоналізованою, а іï реалізація повинна забезпечувати вільний стабільний професійний розвиток майбутнього вчителя. Програми 3 дисциплін педагогічного циклу повинні мати розвиваючий характер, а для цього вони повинні: бути спрямовані на максимальне задоволення інтелектуальних, духовних і професійних запитів як студента, так і викладача; бути орієнтовані на розвиток їх педагогічних здібностей і педагогічного мислення; формувати педагогічну направленість особистості; враховувати особливості впливу акцентуацій характеру студента на продуктивність майбутньої професійної діяльності.

Сьогодні головним напрямом роботи педагогічної кафедри факультету іноземної філології університету $\epsilon$ перехід від масово репродуктивної до розвиваючої, творчої й особистісної освіти, що створює умови для виявлення $\mathrm{i}$ формування творчої індивідуальності майбутнього вчителя (Радую,2014).

Таким чином, викладання дисциплін педагогічного циклу повинно здійснюватись як супровід i забезпечення професійного розвитку i саморозвитку майбутнього вчителя через організацію різних видів як педагогічної, так й інших видів діяльності. Аби встановити особливості формування професійно-педагогічної спрямованості майбутнього вчителя іноземних мов, необхідно з'ясувати особливості фахової підготовки майбутнього вчителя англійської мови. Визначаючи зміст поняття «готовність до іншомовного спілкування», Л. Гапоненко стверджує, що це «складне

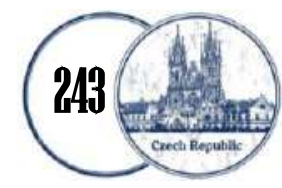


особистісне утворення, яке містить у собі усвідомлене використання студентами іншомовного спілкування як способу професійної взаємодії й засобу обміну професійною інформацією, практичні вміння реалізації комунікативної взаємодії іноземною мовою. Воно спрямоване на підвищення рівня професіоналізму майбутнього вчителя» (Бондаренко, 2008).

Готовність як інтегральне утворення особистості, що полягає у вибірковій спрямованості на педагогічну діяльність, виникає на грунті позитивного ставлення і скеровується відповідними потребами та мотивами до даної діяльності. Про сформовану готовність можна говорити лише за умови розвинутості у суб'єкта емоційного ставлення, вміння адаптувати свою поведінку відповідно до ситуацій, що виникають, вміння будувати процес спілкування, сформованості таких педагогічних здібностей як мислення, уявлення, спостережливість, комунікативних умінь i широкого набору професійно значущих властивостей: емоційної стабільності, самоконтролю, щирості, доброти, наполегливості.

Науковці виділяють певні рівні й етапи у процесі професійного розвитку особистості, зокрема Т. Кудрявцев вважає, що одним 3 провідних критеріїв $\epsilon$ ставлення особистості до професії і рівень виконання діяльності та виділяє чотири стадії професійного розвитку: виникнення та формування професійних намірів; професійне навчання i підготовка до професійної діяльності; входження у професію, активне ії засвоєння й визначення себе у професійній групі або колективі; повна реалізація особистості у професійній діяльності. Стадія професійного навчання та підготовки до педагогічної діяльності майбутнього вчителя характеризується самопроєктуванням на основі усвідомлення змісту діяльності в професійні цінності та структурування концептуальної професійно-педагогічної позиції.

Становлення професійної позиції майбутнього вчителя іноземної мови засобами формування рефлексії, самооцінки й самосвідомості забезпечуються виконанням у професійно-педагогічній підготовці цілісної системи трьох принципів: рефлексивності, інтерактивності й проєктного підходу. Якщо виконання принципу рефлексивності забезпечує осмислення педагогічних цінностей i професійної діяльності, наділення їх власними смислами, інтерактивності (співвіднесення цих смислів зі світом соціальних значень і цінностей культури), то проєктний підхід забезпечує зворотний до осмислення процес - усвідомлення смислів.

Складовою професійної позиції вчителя $є$ професійна самооцінка, що $є$ оцінкою ним самого себе, своїх педагогічних можливостей, професійних якостей і ролі у творчому самотворенні та творенні оточуючих обставин. Професійно цінні якості майбутнього вчителя, що $\epsilon$ складовою його професійної підготовки, відпрацьовуються у тренінгових вправах, розвиваючи здатність до самоосмислення. У процесі дослідження проблеми підготовки 
майбутнього вчителя до професійної діяльності Н. Боритко виділяє такі результати змісту освітнього процесу у ЗВО: перший - рефлексивний (переживання ситуацій педагогічної діяльності, їх обговорення, герменевтичне розуміння їх смислів і значень), другий - ціннісний (осмислення й усвідомлення ситуацій, що дозволяє оформити смисли діяльності в особистісні (індивідуальні) цінності); третій - проєктивний (самопроєктування й реалізація професійної позиції й діяльності, формування ціннісних орієнтирів педагога, усвідомлення принципів його діяльності). У тренінгових вправах, що $\epsilon$ частиною професійної підготовки, відпрацьовуються такі професійно цінні властивості вчителя, як здатність до самоосмислення (розуміння себе), здатність «віддаватися чужому буттю» [1].

Зміст професійної підготовки майбутніх учителів іноземних мов забезпечують Рекомендації Ради Свропи, які конкретизують знання і вміння, які потрібно розвивати у користувачів мови для ефективного спілкування у крос-культурному контексті, пропонують комунікативні педагогічні завдання для активного залучення учнів до осмисленої комунікації та характеризують рівні володіння мовленням на кожному ступені навчання.

Найважливішим завданням професійної підготовки студентів у вищому мовному навчальному закладі $\epsilon$ формування необхідного і достатнього рівня професійної компетенції майбутнього вчителя іноземної мови засобами визначення цілей, врахування специфіки вирішення навчальних завдань щодо формування загальної та комунікативної компетенцій учнів засобами вдосконалення володіння видами мовленнєвої діяльності у конкретній сфері спілкування. Важливим компонентом професійної компетенції майбутнього «я» є також професійна самооцінка, що є оцінкою ним самого себе, своїх педагогічних можливостей, професійних якостей $\mathrm{i}$ ролі в творчому самотворенні та творенні оточуючих обставин.

Професійно цінні якості майбутнього вчителя, що $є$ складовою його професійної підготовки, відпрацьовуються у тренінгових вправах, розвиваючи здатність до самоосмислення. У процесі дослідження проблеми підготовки майбутнього вчителя до професійної діяльності Н. Боритко виділяє такі результати забезпечення змісту освітнього процесу у ЗВО: перший рефлексивний (переживання ситуацій педагогічної діяльності, їх обговорення, герменевтичне розуміння їх смислів i значень), другий - ціннісний (осмислення й усвідомлення ситуацій, що дозволяє оформити смисли діяльності в особистісні (індивідуальні) цінності; третій - проєктивний (самопроєктування й реалізація професійної позиції й діяльності, формування ціннісних орієнтирів педагога, майбутнього вчителя у даному навчальному процесі повинна визначатися тим, що загальною метою викладання профільних дисциплін $є$ орієнтація на індивідуалізацію навчання і соціалізацію учнів, на підготовку до усвідомленого і відповідального вибору сфери

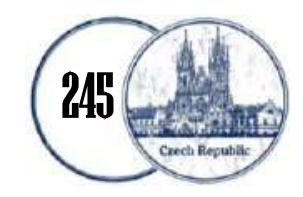


майбутньої професійної діяльності. Відповідно до цього, зміст профільного навчання має бути спрямований на формування в учнів орієнтовних ключових компетентностей, що визначають успішну самореалізацію в умовах постійно змінюваного суспільства: самостійні рефлексивні дії; адекватне використання інструментарію (знарядь праці, технологій, мисленнєвих прийомів) для вирішення проблем; робота в колективі, співробітництво; творче і критичне мислення. Дидактична організація профільного навчання передбачає співпрацю учнів, учителів і батьків у напрямі розвитку траєкторії варіанту освіти категорії учнів (групи, класу, підгрупи тощо) засобами профільнодиференційованого навчання.

Важливим компонентом професійної компетенції майбутнього вчителя іноземних мов $\epsilon$ професійні знання 3 педагогіки, психології, методики викладання іноземних мов, прикладної лінгвістики та вміння їх практичного використання у практичній педагогічній діяльності в закладі загальної середньої освіти, визначені галузевим стандартом вищої освіти.

На думку науковців, «змістом професійних знань майбутнього вчителя $\epsilon$ понятійно-фактична складова навчального матеріалу, яка включає взаємопов'язані факти, закономірності, теорії, узагальнення, терміни»

Отже, професійна підготовка майбутніх учителів англійської мови потребує, крім засвоєння теоретичних знань, формування практичних професійних умінь застосування сучасних інноваційних технологій навчання учнів. Важливо зазначити, що у концепції Оксфордського університету базової підготовки вчителя акцентується увага на вирішенні фундаментальної проблеми взаємозв'язку теорії i практики: критичного вивчення, вдосконалення та експериментального використання практичних педагогічних ідей, різноманітної теоретичної та науково-дослідної літератури, тобто «практичне теоретизування».

На переконання С. Вітвицької, «процес засвоєння професійних знань тісно пов'язаний з розвитком професійного мислення, завдяки якому студенти здатні виділяти істотні ознаки педагогічних фактів, явищ, ситуацій, аргументувати їх, прогнозувати результат, приймати власне рішення». Автор виділяє п’ять рівнів сформованості у студентів професійних знань:

- н на першому рівні (розуміння) можуть визначити та інтерпретувати сутність базових фахових понять на основі їх категоріального аналізу;

- $\quad$ на другому (застосування) - використовують знання сутності базових фахових понять у стандартних ситуаціях під керівництвом викладача;

на третьому (аналіз) - співставляють основні категорії, визначають взаємозв'язок між ними, використовують набуті знання у нестандартних ситуаціях;

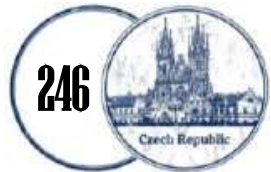


на четвертому (синтез) - встановлюють логіко-структурну залежність між основними педагогічними поняттями, розробляють опорні схеми окремих питань, виступають 3 доповідями, повідомленнями;

- $\quad$ на п'ятому ( оцінка) - оцінюють значення того чи іншого матеріалу у цілісній системі професійних знань, грунтуючись на чітких критеріях оцінки [6].

Отже, головною властивістю професійних знань студента є усвідомлена вмотивованість вибору ним способу виконання педагогічної дії, на основі оволодіння засобами та прийомами та застосування засвоєних знань на практиці.

Моделюючи зміст й структуру професійної діяльності майбутнього вчителя іноземної мови, С. Пассов визначив вісім видів умінь, на розвиток яких слід спрямувати процес професійної підготовки: проєктувальні (вміння спроектувати, спланувати будь-який вид роботи); адаптаційні (вміння застосовувати свій план у конкретних навчальних умовах); організаційні (вміння організовувати будь-який вид роботи); мотиваційні (вміння мотивувати учнів до навчальної діяльності); комунікативні (вміння спілкуватися на уроці і поза ним); уміння контролю і самоконтролю; пізнавальні (вміння вести дослідницьку діяльність); допоміжні (вміння співати, малювати, грати на музичному інструменті тощо).

Важливо зазначити, що сформованість зазначених вище вмінь забезпечує загальнометодичну підготовку вчителя іноземних мов, що дозволить йому працювати як у різних типах 3ВО, так і на різних рівнях навчання закладів загальної середньої освіти - початковому, базовому і профільному.

Завершальним етапом у професійній підготовці майбутнього вчителя IM до роботи в старшій школі $\epsilon$ процес оволодіння професійною компетенцією зокрема: набуття професійних знань про особливості організації навчального процесу з IM на старшому ступені: послідовне здійснення комунікативнопізнавального навчання, використання прийомів особистісно-орієнтованого оволодіння іншомовною комунікативною компетенцією на рівні $\mathrm{B} 1+$ (просунутий рубіжний рівень), цілеспрямована реалізація принципу професійної спрямованості навчання IM, орієнтована на використання IM у майбутній практичній діяльності старшокласників, активне застосування індивідуальних і групових форм самостійної роботи.

Технологічне забезпечення професійної компетенції майбутнього вчителя англійської мови, на нашу думку, корелює з основним методологічним принципом Ради Європи: методи, що використовуються у вивченні, викладанні та дослідженні мов, мають розглядатися з точки зору їх найбільшої ефективності для досягнення цілей, узгоджених із потребами окремих учнів у ïx соціальному контексті. Дотримання зазначеного фундаментального 
принципу неухильно приводить до великої різноманітності методів і засобів навчання. Сучасний підхід, який запроваджується Радою Свропи, базується на комунікативних потребах учнів та використанні засобів i методів, які допоможуть учням задовольняти ці потреби і які відповідають їх характеристикам як учнів. Проте перспективним вважається представлення різних напрямів, що сприятиме глибинному розумінню комплексної різноманітності сфери мовної освіти. Навчальні технології як шляхи засвоєння конкретного навчального матеріалу в межах професійної підготовки вчителя іноземних мов варіюються залежно від форми навчання.

Провідною формою навчання у вищому навчальному закладі, як відомо, $\epsilon$ лекція, дидактичним завданням якої $є$ не тільки ознайомлення студентів 3 основним змістом, принципами, закономірностями, головними ідеями, а й спрямування міркувань для подальшої самостійної роботи студентів [6].

Сучасна лекція, зокрема 3 професійно-методичних дисциплін, повинна відповідати таким основним технологічним вимогам: забезпечити діалог 3 аудиторією для активного залучення слухачів до навчального процесу; звертатися до досвіду і знань аудиторії для спільного опрацювання матеріалу; організовувати вільний обмін думками в інтервалах між логічними розділами 3 метою активізації пізнавальної діяльності аудиторії; створювати проблемні ситуації як засіб стимулювання професійного мислення. Для цього доцільно використовувати такі навчальні технології, як евристична бесіда, мозковий штурм, дискусія, проблемне завдання. На семінарсько-практичних заняттях із метою розвитку професійного мислення, пізнавальної мотивації i професійного використання знань у навчальних умовах набувають поширення групові технології, які передбачають підготовку до виконання групового завдання вирішити пізнавальне завдання, групової роботи (знайомство 3 матеріалом, планування роботи, виконання індивідуальних завдань, обговорення отриманих результатів), висновки про роботу групи і виконання поставленого завдання. Творчі майстерні працюють із залученням ігрових технологій - ділових, рольових, імітаційних, операційних ігор, які дають можливість студентам зрозуміти навчальний матеріал різних позицій і набути первинного педагогічного досвіду. Для організації лабораторних робіт у професійній підготовці вчителя IM доцільними $\epsilon$ технічні інформаційні технології. Це процес підготовки і передачі конкретної інформації, засобом якої є відео, комп'ютер та інші технічні засоби. Перегляд відеоуроків із взаємопов'язаним виконанням завдання на цілеспрямоване спостереження за навчальним процесом, їх подальше обговорення і пошук шляхів оптимізації певної професійно-педагогічної ситуації поєднують особистісний і діяльнісний компоненти навчання. Комп’ютерні технології можуть здійснюватися як "проникнення" в окремі теми курсу, що забезпечить багатократне збільшення 
релевантної інформації, створить інформаційне середовище і посилить інтерактивний характер навчання.

Розмаїття технологічного забезпечення процесу формування професійної компетенції майбутнього вчителя IM уможливлює сприяння розвитку індивідуальних когнітивних стилів студентів у рамках особистісноорієнтованого навчання. Центром такого навчання є особистість студента, його самобутність, самоцінність; суб'єктний досвід кожного спочатку розкривається, а потім узгоджується зі змістом освіти.

Стосовно процесу становлення професійної особистості, головними вимогами до особистісно орієнтованих технологій вважаються:

виявлення та оцінка способів навчальної роботи, якими користується студент самостійно, стійко, продуктивно;

- $\quad$ урахування і розвиток когнітивних стилів студентів через індивідуалізовані завдання, поширені частки самостійної роботи в опрацюванні навчального матеріалу, використання різних видів наочності як засобів підвищення рівня мотивації до оволодіння професійними знаннями і вміннями;

- активне стимулювання студента до самоосвіти, саморозвитку, самовираження у ході опанування знань;

- $\quad$ конструювання і організація навчального матеріалу, який дає змогу студенту вибрати його зміст, вид та форму при виконанні завдань, рішенні задач тощо.

Ефективною технологією особистісно орієнтованого навчання $є$ робота над навчальним проєктом, яка передбачає самостійну діяльність студентів індивідуальну, парну або групову - 3 метою розв'язання певної професійної проблеми, що вимагає, з одного боку, використання різноманітних методів, засобів навчання, а $з$ іншого - інтегрування знань, умінь 3 різних галузей науки, творчості.

Результати виконання проєктів повинні бути «відчутні», тому проєктна технологія передбачає застосування студентами всієї сукупності професійних умінь, згаданих вище.

Отже, огляд професійної підготовки майбутнього вчителя англійської мови у контексті європейських вимог виявляє ряд загальних тенденцій, які можуть посилити професіоналізм, розумову культуру студентів, відповідальність за результати своєї навчальної праці на рівні визначення нових цілей і змісту навчання, використання сучасних навчальних технологій, сприяння розвитку індивідуальних, когнітивних стилів i здійснення адекватного контролю за рівнем сформованості професійних знань і умінь. Майбутній вчитель англійської мови має усвідомити, що загальною метою викладання профільних дисциплін $є$ орієнтація на індивідуалізацію навчання і соціалізацію учнів, на підготовку до усвідомленого і відповідального вибору

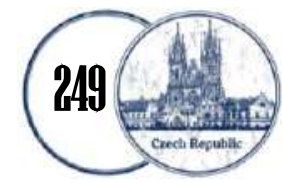


сфери майбутньої професійної діяльності. Відповідно до цього, зміст профільного навчання має бути спрямований на формування в учнів орієнтовних ключових компетентностей, що визначають успішну самореалізацію в умовах постійно змінюваного суспільства: самостійні рефлексивні дії; адекватне використання інструментарію (знарядь праці, технологій, мисленнєвих прийомів) для вирішення проблем; робота в колективі, співробітництво; творче i критичне мислення. Дидактична організація профільного навчання передбачає співпрацю учнів, учителів i батьків у напрямі розвитку траєкторії варіанту освіти категорії учнів (групи, класу, підгрупи тощо) засобами профільно-диференційованого навчання.

Висновки. Роблячи підсумок розгляду вищезгаданих понять 3 позицій інноваційних підходів до підготовки майбутніх учителів англійської мови, ми можемо зробити такі висновки:

Специфіка профілізації старшої школи висуває нові, підвищені вимоги до професійного рівня майбутнього вчителя англійської мови:

- забезпечення варіативності та особистісної орієнтації освітнього процесу, проєктування індивідуальних освітніх траєкторій;

- практична орієнтація освітнього процесу із введенням інтерактивних діяльнісних компонентів (засвоєння проєктно-дослідницьких і комунікативних методів);

- завершення профільного самовизначення старшокласників i формування ключових компетентностей, необхідних для продовження освіти у відповідній сфері професійної освіти.

Однією із провідних ідей підготовки майбутніх учителів англійської мови до профільного навчання старшокласників є усвідомлення значущості власної педагогічної діяльності у контексті профільного навчання та практичного впровадження набутих професійних знань, умінь і навичок у педагогічній практиці і майбутній професійній діяльності в сучасній школі.

\section{Jimepamypa:}

1. Бібік Н. М. Компетентнісний підхід: рефлексивний аналіз застосування. Компетентнісний підхід у сучасній освіті: світовий досвід та українські перспективи. Бібліотека з освітньої політики / під заг. ред. О. В. Овчарук. Київ : К.І.С., 2004. 47-52 с.

2. Бідюк Н. М. Теоретико-методологічні підходи у навчанні іноземної мови: навч. посіб. для студ. старших курсів ф-тів інозем. мов (англ. мовою). Хмельницький : ХНУ, 2010. $194 \mathrm{c}$.

3. Бондаренко Е. Н. Профессиональная подготовка учителей в современных системах педагогического образования в странах мира. Вестник Московского ун-та. Сер. 20. Педагогическое образование. 2008. № 3. С. 127-136.

4. Вітвицька С. С. Педагогічна підготовка магістрів в умовах ступеневої освіти : теоретико-методологічний аспект : монографія. Житомир : Вид-во ЖДУ імені І. Франка, 2009. $440 \mathrm{c}$. 
5. Гафурова Н. В., Лях В. И. Разработка и реализация предпрофильного образования в рамках сетевой модели «школа-вуз». Школьные технологии. 2005. № 5. С. 94-104.

6. Дьяченко М. И., Кандыбович Л. А. Психологические проблемы готовности к деятельности. Минск : БГУ, 1976. 173 с.

7. Козолуп М. С. Академічна комунікативна підготовка студентів у ВНЗ: компетентнісний підхід. Вісник Житомирського державного університету імені Івана Франка: науковий журнал. Педагогічні науки. Житомир: Вид-во Житомирського держ. унту імені І. Франка, 2018. Вип.2. №93. С. 80-85.

8. Курило В. С. Моделювання системи критеріїв оцінки розвитку освіти в регіоні. Педагогіка і психологія. 1999. № 2. С. 35-39.

9. Радую С. Г. Формування міжкультурної компетентності майбутнього вчителя іноземної мови у процесі професійної підготовки: дис. ... к-та пед. наук: 13.00.04; теорія і методика професійної освіти. Уманський державний педагогічний університет імені Павла Тичини. Умань, 2014. 252 с.

10. Соколова I. В. Професійна підготовка вчителя за двома спеціальностями: концепції, парадигми, моделі. Неперервна професійна освіта: теорія і практика. Київ, 2006. Вип. 3-4. С. 86-94.

\section{References:}

1. Bibik N. M. (2004) Kompetentnisnyi pidkhid: refleksyvnyi analiz zastosuvannia. [Competence approach: reflexive analysis of application.] Kompetentnisnyi pidkhid u suchasnii osviti: svitovyi dosvid ta ukrainski perspektyvy. Biblioteka z osvitnoi polityky / pid zah. red. O. V. Ovcharuk. Kyiv : K.I.S. 47-52 s. [in Ukrainian].

2. Bidiuk N. M. (2010) Teoretyko-metodolohichni pidkhody u navchanni inozemnoi movy: navch. posib. dlia stud. starshykh kursiv f-tiv inozem. mov (anhl. movoiu) [Theoretical and methodological approaches in teaching a foreign language: textbook. way. for students. senior courses of foreign universities. as]. Khmelnytskyi : KhNU. 194 s.[in English].

3. Bondarenko E. N. (2008) Professionalnaia podgotovka uchitelei v sovremennykh sistemakh pedagogicheskogo obrazovaniia $\mathrm{v}$ stranakh mira. [Professional training of teachers in modern systems of pedagogical education in the countries of the world]. Vestnik Moskovskogo un-ta. Ser. 20. Pedagogicheskoe obrazovanie. № 3. S. 127-136. [in Russian].

4. Vitvytska S. S. (2009) Pedahohichna pidhotovka mahistriv v umovakh stupenevoi osvity : teoretyko-metodolohichnyi aspect [Pedagogical training of masters in terms of higher education: theoretical and methodological aspect] : monohrafiia. Zhytomyr : Vyd-vo ZhDU imeni I. Franka. 440 s. [in Ukrainian].

5. Gafurova N. V., Liakh V. I. (2005) Razrabotka i realizatciia predprofilnogo obrazovaniia v ramkakh setevoi modeli «shkola-vuz». [Development and implementation of pre-professional education within the network model "school-university".]. Shkolnye tekhnologii. № 5. S. 94-104. [in Russian].

6. Diachenko M. I., (1976) Kandybovich L. A. Psikhologicheskie problemy gotovnosti k deiatelnosti.[ Psychological problems of readiness for activity.] Minsk : BGU. $173 \mathrm{~s}$. [in Russian].

7. Kozolup M. S. (2018) Akademichna komunikatyvna pidhotovka studentiv u VNZ: kompetentnisnyi pidkhid. [Academic communicative training of students in higher education: competence approach]. Visnyk Zhytomyrskoho derzhavnoho universytetu imeni Ivana Franka: naukovyi zhurnal. Pedahohichni nauky. Zhytomyr: Vyd-vo Zhytomyrskoho derzh. un-tu imeni I. Franka, Vyp.2. №93. S. 80-85. [in Ukrainian].

8. Kurylo V. S. (1999) Modeliuvannia systemy kryteriiv otsinky rozvytku osvity v rehioni. [Modeling of the system of criteria for assessing the development of education in the region]. Pedahohika i psykholohiia. № 2. S. 35-39. [in Ukrainian]. 
9. Raduiu S. H. (2014) Formuvannia mizhkulturnoi kompetentnosti maibutnoho vchytelia inozemnoi movy u protsesi profesiinoi pidhotovky [Formation of intercultural competence of the future foreign language teacher in the process of professional training]: dys. ... k-ta ped. nauk: 13.00.04; teoriia i metodyka profesiinoi osvity. Umanskyi derzhavnyi pedahohichnyi universytet imeni Pavla Tychyny. Uman, 252 s. [in Ukrainian].

10. Sokolova I. V. (2006) Profesiina pidhotovka vchytelia za dvoma spetsialnostiamy: kontseptsii, paradyhmy, modeli. [Teacher training in two specialties: concepts, paradigms, models]. Neperervna profesiina osvita: teoriia i praktyka. Kyiv, 2006. Vyp. 3-4. S. 86-94. [in Ukrainian]. 